\title{
A Study on Knowledge Level of Farmers on Farm Pond in Koppal District Karnataka, India
}

\author{
H. Shoba ${ }^{1^{*}}$, N. Rajeshwari ${ }^{2}$, P. Pushpa ${ }^{3}$ and H. Yogeeshappa ${ }^{4}$ \\ ${ }^{1}$ Department of Agricultural Engineering, ${ }^{2}$ Department of Spices, Plantation, Medicinal and \\ Aromatic Crops, ${ }^{4}$ Department of Soil Science, \\ College of Horticulture, Munirabad, Karnataka, India \\ ${ }^{3}$ Department of Agricultural Extension, College of Horticulture, Sirsi, Karnataka, India
}

*Corresponding author

\section{A B S T R A C T}

\section{Keywords \\ Adoption, Awareness, Farm Pond, Knowledge, Source \\ Article Info \\ Accepted: \\ 07 October 2018 \\ Available Online: \\ 10 November 2018}

\begin{abstract}
The present study was conducted in ten villages of Koppal District, Karnataka with an objective of to know the knowledge level of farmers on Farm Pond. For conducting the present study ten villages were selected randomly and fifteen respondents from each village were selected purposively to comprise a sample size of 150 respondents. It was observed that, 45.33 percentage of the farmers had the medium knowledge and 29.34 percent had low knowledge whereas 25.33 percent of the farmers had least knowledge on farm pond and majority of the farmers 57.33 percent had awareness on farm pond from KSDA Scheme (Karnataka State Department of Agricultural) whereas the least i.e. 6.66 percent farmers had the awareness on farm pond from News Paper.
\end{abstract}

\section{Introduction}

Rainfall is a basic resource for all the forms of water in semi-arid tropics of India. Though the annual average rainfall of the country is 1200 $\mathrm{mm}$, it varies in both space and time affecting the availability of water for different sectors. India uses $80 \%$ of the available water in agriculture keeping the remaining $20 \%$ for drinking, industry and energy sectors. The growing population puts tremendous pressure on the water resources. The annual per capita water availability has decreased from $5000 \mathrm{~m}^{3}$ in 1950 to $1300 \mathrm{~m}^{3}$ in 2010 and projected to decrease further to below $1000 \mathrm{~m}^{3}$ by 2025 (Anonymous, 2013). About half of India's population depends directly on agriculture. Over 40 percent of food production in the country depends on adequate and timely rainfall. It is high time for the country to explore ways to make farming sustainable by reducing its dependency on uncertain monsoon. Constructing farm ponds to store and manage precious water better could be one of the solutions. A farm pond is a large hole dug out in the earth, usually square or 
rectangular in shape, which harvests rainwater and stores it for future use. It has an inlet to regulate inflow and an outlet to discharge excess water. The pond is surrounded by a small bund, which prevents erosion on the banks of the pond. The size and depth depend on the amount of land available, the type of soil, the farmer's water requirements, the cost of excavation, and the possible uses of the excavated earth. Water from the farm pond is conveyed to the fields manually, by pumping, or by both methods.

The Koppal district occupies an area of $7,190 \mathrm{~km}^{2}$ and has a semi-arid type climate characterized by hot summer and low rainfall. The district is characterized by dryness for the major part of the year because of less rainfall. The annual normal rain fall is $571.92 \mathrm{~mm}$ and Agriculture in Koppal district is dependent upon rainfall, irrigation tanks, wells, streams etc. The major agricultural crops grown are Jawar, Bajra, Wheat, Maize, Paddy, Horsegram, Greengram, Cowpeas and the commercial crops are Groundnut, Till, Cotton, Niger seeds, Castor, Sunflower, Sugarcane etc. The important crops are fruit crops, vegetable crops, plantation crops, spices and flower crops. The major fruit crops include pomegranates, grapes, mango, sapota, citrus, guava, papaya etc. The farm pond has a great impact on changing the crop productivity as well as cropping intensity. The main objective of present research study was to know the knowledge level the farmers on farm pond so as to Govt. and private organization to introduce more and more programmes on to create awareness and benefits of the farm pond to helps in changing the economic situation of the farmers. The irrigated area also increases due to the construction farm pond

\section{Materials and Methods}

Present research work was conducted in Koppal district; Karnataka. The ten villages were randomly selected and in each randomly selected village fifteen respondents were selected by making a sample size of 150 .

For collecting data, a pretested scheduled questionnaire was prepared and by taking personal interview from each respondent the data were collected, tabulated and analyzed.

\section{Results and Discussion}

\section{Overall knowledge level of farmers on Farm pond}

Result shows that, 45.33 percent of the respondents had medium level 29.34 percent had low level and 25.33 percent had high level of knowledge on farm pond this was mainly due to that still some of the farmers of this region were not much aware of farm pond (Table 1).

\section{Awareness of farmer on farm pond from different sources}

Table 2 shows that, the 57.33 percent of the farmers had the awareness on farm pond from KSDA Scheme (Karnataka State Department of Agricultural) where as 21.33 percentage of farmers had the awareness from Television programme and 16.66 percentage farmers had awareness from radio programme whereas least was observed from Krishi Magazine 10 percent and newspapers 6.66 percent

\section{Social and demographic profile of farmers}

Table 3 shows that, the 55 percentage of farmers from the ten villages are the illiterate 22 percentage of farmers are completed Primary Education, 11 percent farmers completed High School whereas 7 percent farmers are completed graduate even though majority of the farmers are illiterates the farmers had the knowledge on the farm pond this was mainly because of the Karnataka 
State Department of Agricultural, Agricultural and Horticultural colleges has conducted different programmes to create awareness and benefits of farm pond

The 45 percentage of farmers are irrigating the lands through canals and 22 percent of farmers are irrigating the land through bore wells whereas 25 percent of farmers depends on the rain fall and least was absorbed from rivers 6 percent. Farm Ponds provide water for irrigation during season between rainfalls and increase the yield of crop, the number of crops, and the diversity of crops that can be grown (Dr. Neeta Andure et al., 2017)

Table.1 Overall knowledge level of the respondents about farm implements

$(\mathrm{n}=150)$

\begin{tabular}{|c|l|c|c|}
\hline Sl. No & \multicolumn{1}{|c|}{ Category } & Frequency & Percentage (\%) \\
\hline $\mathbf{1}$ & low (Mean $-0.425^{*}$ SD) & 45 & 29.34 \\
\hline $\mathbf{2}$ & Medium (Mean $\pm 0.425^{*}$ SD) & 68 & 45.33 \\
\hline $\mathbf{3}$ & High (Mean $+0.425 *$ SD) & 38 & 25.33 \\
\hline
\end{tabular}

Source: Primary data

Table.2 Awareness of farmer on farm pond from different sources

\begin{tabular}{|c|c|c|c|}
\hline $\begin{array}{l}\text { SI } \\
\text { No }\end{array}$ & Sources & Frequency & $\begin{array}{c}\text { Percentage of } \\
\text { Awareness } \\
(\%)\end{array}$ \\
\hline 1. & $\begin{array}{l}\text { KSDA (Karnataka State Agricultural } \\
\text { Department) }\end{array}$ & 86 & 57.33 \\
\hline 2. & Television & 32 & 21.33 \\
\hline 3. & Radio & 25 & 16.66 \\
\hline 4. & Krishi Magazines & 15 & 10.00 \\
\hline 5. & News Papers & 10 & 6.66 \\
\hline
\end{tabular}

Table.3 Social and Demographic profile of farmers

\begin{tabular}{|l|l|c|c|}
\hline $\begin{array}{l}\text { SI } \\
\text { No }\end{array}$ & Education knowledge & Frequency & $\begin{array}{c}\text { Percentage } \\
(\%)\end{array}$ \\
\hline 1. & Illiterate & 83 & 55 \\
\hline 2. & Primary school & 33 & 22 \\
\hline 3. & High school & 17 & 11 \\
\hline 4. & Graduate & 11 & 7 \\
\hline & Sources for irrigation & & \\
\hline 1. & Bore well & 33 & 22 \\
\hline 2. & Canal & 68 & 45 \\
\hline 3. & River & 10 & 6 \\
\hline 4. & Others (Rain fed) & 38 & 25 \\
\hline
\end{tabular}

Source: Primary data 
Table.4 Categories of farmer's knowledge level on farm pond

\begin{tabular}{|c|c|c|c|}
\hline SL. & Categories & Frequency & $\begin{array}{c}(\mathrm{n}=150) \\
\text { Percentage } \\
(\mathbf{\%})\end{array}$ \\
\hline $\mathbf{1}$ & Small Farmers & 26 & 17.3 \\
\hline $\mathbf{2}$ & Medium Farmer & 42 & 28.0 \\
\hline $\mathbf{3}$ & Large Farmer & 82 & 54.7 \\
\hline Source: Primary data & & \\
\hline
\end{tabular}

Categories of farmer's knowledge level on farm pond

Table 4 shows that, the large farmers had 54.7 $\%$ knowledge level medium farmers had 28 percentage knowledge level whereas small farmers had 17.3 percent knowledge level this was mainly due to large and medium farmers are illiterates

\section{Acknowledgement / Funding}

Author is thankful to University of Horticultural Sciences, Bagalkot, Karnataka, India for support to carry out present work successfully.

\section{Author contributions}

All authors are equally contributed

Farm ponds would help the farmers for on farm water management by using stored water for tackling the drought or dry spells during the off season. Farm pond has been recognized as an important component for changing socioeconomics and generating more income for poor farming households. Ponds add value to farming activities: water from ponds can serve domestic and livestock water supplies as well as irrigation for crops. Raising fish is an obvious use for a farm pond; it adds value to the water and provides improved nutrition for farm families. This research provides basic and practical knowledge level of farmers on farm pond and the role of government, state agricultural departments, developed organizations to opportunities for providing assistance, direct and indirect support required, strategic and technical challenges for making farmers to self-reliant.

\section{References}

Anonymous, 2013. Impact of farm ponds on beneficiary farmers of Western Vidarabha, Research Review Committee Project, submitted on 2nd April, 2013 at RRC meeting Dr. Punjanbrao Deshmukh Krishi Vidyapeeth, Akola.

Deshmukh, J.M., V.D. Hyalij, D.D. Suradkar and Badgire, B.B. (2017). Impact Assessment of Farm Ponds on Beneficiaries. Int.J.Curr.Microbiol. App.Sci. 6(9): 1712-1717.

http://cgwb.gov.in/District_Profile/karnataka/ 2012/KOPPA-2012L.pdf

Mane, N.P., Ulemale, D.H. and Thakare, S.S. (2015). A comparative analysis on impact of farm pond's on farmer's economy in Amravati district. Internat. Res. J. Agric. Eco. \& Stat., 6 (2): 287292.

Munyaneza, O., Majoro, F., Hagenimana, E. and Usabyisa, W. (2016) Impact Assessment of Hillside Rainwater Harvesting Ponds on Agriculture Income: Case Study of Ntarama Sector in Rwanda. Journal of Water Resource and Protection, 8, 844-854.

Neeta Andure., A. A. Varma., A.S. Lanjewar, V. R. Kadam. (2017). "A Study of the 
Impact of Farm Pond on the Farmers in Amravati Taluka Region" international journal of scientific research volume no 6(4): pg no $734-737$.
Reddy, K.S., FARM PONDS: A Climate Resilient Technology for Rain fed Agriculture. Technical Bulletin: 3/2012.

\section{How to cite this article:}

Shoba, H., N. Rajeshwari, P. Pushpa and Yogeeshappa, H. 2018. A Study on Knowledge Level of Farmers on Farm Pond in Koppal District Karnataka, India. Int.J.Curr.Microbiol.App.Sci. 7(11): 613-617. doi: https://doi.org/10.20546/ijcmas.2018.711.074 